\title{
Radiative impact of mineral dust on monsoon precipitation variability over West Africa
}

\author{
C. Zhao, X. Liu, L. Ruby Leung, and S. Hagos \\ Atmospheric Science and Global Change Division, Pacific Northwest National Laboratory, Richland, WA, USA
}

Received: 4 November 2010 - Published in Atmos. Chem. Phys. Discuss.: 10 November 2010

Revised: 17 February 2011 - Accepted: 22 February 2011 - Published: 1 March 2011

\begin{abstract}
The radiative forcing of dust and its impact on precipitation over the West Africa monsoon (WAM) region is simulated using a coupled meteorology and aerosol/chemistry model (WRF-Chem). During the monsoon season, dust is a dominant contributor to aerosol optical depth (AOD) over West Africa. In the control simulation, on 24-h domain average, dust has a cooling effect $\left(-6.11 \mathrm{~W} \mathrm{~m}^{-2}\right)$ at the surface, a warming effect $\left(6.94 \mathrm{~W} \mathrm{~m}^{-2}\right)$ in the atmosphere, and a relatively small TOA forcing $\left(0.83 \mathrm{~W} \mathrm{~m}^{-2}\right)$. Dust modifies the surface energy budget and atmospheric diabatic heating. As a result, atmospheric stability is increased in the daytime and reduced in the nighttime, leading to a reduction of late afternoon precipitation by up to $0.14 \mathrm{~mm} / \mathrm{h}(25 \%)$ and an increase of nocturnal and early morning precipitation by up to $0.04 \mathrm{~mm} / \mathrm{h}$ $(45 \%)$ over the WAM region. Dust-induced reduction of diurnal precipitation variation improves the simulated diurnal cycle of precipitation when compared to measurements. However, daily precipitation is only changed by a relatively small amount $(-0.17 \mathrm{~mm} /$ day or $-4 \%)$. The dust-induced change of WAM precipitation is not sensitive to interannual monsoon variability. On the other hand, sensitivity simulations with weaker to stronger absorbing dust (in order to represent the uncertainty in dust solar absorptivity) show that, at the lower atmosphere, dust longwave warming effect in the nighttime surpasses its shortwave cooling effect in the daytime; this leads to a less stable atmosphere associated with more convective precipitation in the nighttime. As a result, the dust-induced change of daily WAM precipitation varies from a significant reduction of $-0.52 \mathrm{~mm} /$ day $(-12 \%$, weaker absorbing dust) to a small increase of $0.03 \mathrm{~mm} /$ day (1\%, stronger absorbing dust). This variation originates from the competition between dust impact on daytime and night-
\end{abstract}

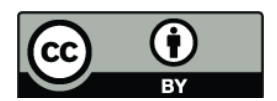

Correspondence to: C. Zhao (chun.zhao@pnl.gov) time precipitation, which depends on dust shortwave absorption. Dust reduces the diurnal variation of precipitation regardless of its absorptivity, but more reduction is associated with stronger absorbing dust.

\section{Introduction}

The West African Monsoon (WAM) system is a major climate system and an important component of the regional hydrological cycle on which the livelihood of a large and growing population over Sahel depends [Sultan et al., 2005]. The WAM regulates the seasonal cycle of dry and wet seasons in response to annual cycle in solar forcing. The Sahara desert over West Africa is the largest source of mineral dust aerosol in the world (e.g., Woodward, 2001; Prospero et al., 2003). The Saharan dust emitted during the WAM season can significantly affect the WAM development and precipitation, because it interacts with both shortwave (SW) and longwave (LW) radiation, and modifies the radiative and physical properties of clouds (e.g., Miller et al., 2004; Yoshioka et al., 2007; Konare et al., 2008; Lau et al., 2009; Kim et al., 2010).

Recognizing that dust may significantly modify climate at the regional scale (e.g., Miller et al., 2004; Yoshioka et al., 2007; Konare et al., 2008; Solmon et al., 2008; Lau et al., 2009; Kim et al., 2010), many efforts have begun in recent years to study the Saharan dust effect on WAM precipitation. Most of these studies used general circulation models (GCMs) and have provided important understanding of the fundamental processes associated with dust effect on precipitation during the WAM season. Miller et al. (2004) found that precipitation may be enhanced locally over the Sahel in response to the radiative forcing of dust, while Yoshioka et al. (2007) showed that rainfall is reduced over the Sahel due to weakly absorbing dust. Yoshioka et al. (2007) estimated that $\sim 30 \%$ of the observed precipitation reduction in the Sahel from the 1950 s to 1980 s may be attributed to dust. Lau

Published by Copernicus Publications on behalf of the European Geosciences Union. 
et al. (2009) and Kim et al. (2010) showed that dust radiative effect may strengthen the WAM, which is manifested in a northward shift of the West Africa precipitation over land. Kim et al. (2010) also found that dust may affect not only the total amount but also diurnal cycle of WAM precipitation. Solmon et al. (2008), using a regional climate model, showed that the WAM precipitation response to dust radiative forcing is highly sensitive to the absorption properties of dust.

Although all previous studies mentioned above are consistent with enhanced precipitation due to dust-induced atmospheric heating and reduced precipitation due to dustinduced surface cooling, they differ in concluding whether the presence of dust is more likely to increase or decrease precipitation over the Sahelian region. The main reason for the contrasting conclusions lies in the difficulty in estimating the radiative effect of mineral dust. Dust radiative forcing occurs in both the LW and SW spectral bands and at the surface and within the atmosphere, which can trigger different warming/cooling effects that lead to opposite climatic responses. The difficulty also comes from large uncertainty in the absorbing properties of dust (Balkanski et al., 2007; McConnell et al., 2010). A full understanding of how various forcings of dust jointly alter the surface energy budget and atmospheric dynamics as well as both the total amount and diurnal cycle of precipitation remains challenging.

Previous studies of dust radiative impact on WAM precipitation were mostly performed using prescribed dust aerosol in GCMs. Because of the coarse horizontal resolution (typically $2^{\circ} \times 2.5^{\circ}$ ), WAM precipitation and its diurnal variation are not well simulated (e.g., Lau et al., 2009; Kim et al., 2010). Therefore, dust effects on the regional hydrological cycle in the WAM region could be misrepresented due to biases in the simulated precipitation. This study uses a regional model (Weather Research and Forecasting (WRF) model (Skamarock et al., 2008)) with relatively high horizontal resolution of $36 \times 36 \mathrm{~km}^{2}$ and online dust calculation (Zhao et al., 2010) to understand the response of WAM precipitation to Saharan dust. The WRF model has been used in many regional air quality and climate studies (e.g., Fast et al., 2006 and 2009; Leung et al., 2006; Wang and Liu, 2009; Qian et al., 2009; Zhang et al., 2009) including some over Africa (e.g., Vigaud et al., 2009; Zhao et al., 2010). In this study, we use a version of WRF (WRF-Chem) that simulates trace gases and particulates simultaneously with the meteorological fields (Grell et al., 2005). Zhao et al. (2010) investigated the sensitivity of the WRF-Chem simulated dust radiative forcings to dust emission and aerosol schemes and evaluated the model results using data from the African Monsoon Multidisciplinary Analysis (AMMA) campaign, which is a major international campaign in 2006 to improve understanding of climate, monsoon, and hydrological cycle of West Africa and the impacts from aerosols (Redelsperger et al., 2006).
Following a similar modeling approach as Zhao et al. (2010), the objective of this study is to further understand the various radiative forcings of Saharan dust and how they jointly affect the surface energy budget, atmospheric diabatic heating, and hydrological cycle at a regional scale. Building on our recent study (Zhao et al., 2010), this work (1) examines both SW and LW radiative forcings of Saharan dust during the wet monsoon season over West Africa, and (2) investigates the potential dust effects on precipitation during the WAM season. The paper is organized as follows. Sections 2 and 3 detail the WRF-Chem model and the measurements used in this study. The SW and LW radiative forcings of Saharan dust and their impact on the WAM precipitation are analyzed in Sect. 4. The paper concludes in Sect. 5.

\section{Model description}

WRF-Chem, a version of WRF (Skamarock et al., 2008), simulates trace gases and particulates simultaneously with the meteorological fields (Grell et al., 2005). Early versions of WRF-Chem include the RADM2 (Regional Acid Deposition Model 2) photochemical mechanism (Stockwell et al., 1990) and the MADE/SORGAM (Modal Aerosol Dynamics Model for Europe (MADE) and Secondary Organic Aerosol Model (SORGAM)) aerosol model (Ackermann et al., 1998; Schell et al., 2001). The CBM-Z (Carbon Bond Mechanism) photochemical mechanism (Zaveri and Peters, 1999) and MOSAIC (Model for Simulating Aerosol Interactions and Chemistry) aerosol model (Zaveri et al., 2008) were later implemented by Fast et al. (2006) into WRF-Chem, together with more complex treatments of aerosol radiative properties and photolysis rates. MADE/SORGAM in WRF-Chem uses the modal approach with three modes (Aitken, accumulation, and coarse modes, assuming a log-normal distribution within each mode) to represent the aerosol size distribution, while MOSAIC uses a sectional approach where aerosol size distribution is divided into discrete size bins defined by their lower and upper dry particle diameters. Generally, a modal approach is less accurate because of its assumption of lognormal size distribution and limited number of modes, but it is less computationally demanding than a sectional approach that uses more bins. Each size mode (or bin) is assumed internally mixed so that all particles within a size mode (or bin) are assumed to have the same chemical composition. In both MADE/SORGAM and MOSAIC, aerosols are composed of sulfate, nitrate, ammonium, organic matters $(\mathrm{OM})$, black carbon (BC), water, sea salt and mineral dust. Aerosol optical properties such as extinction, single-scattering albedo, and asymmetry factor for scattering are computed as a function of wavelength and three-dimensional position. Each chemical constituent of the aerosol is associated with a complex refraction index calculated by volume averaging for each size bin (or mode), and Mie theory is used to compute the extinction efficiency $\left(\mathrm{Q}_{\mathrm{e}}\right)$ and the scattering efficiency $\left(\mathrm{Q}_{\mathrm{s}}\right)$. To 
efficiently compute $\mathrm{Q}_{\mathrm{e}}$ and $\mathrm{Q}_{\mathrm{s}}$, WRF-Chem uses a methodology described by Ghan et al. (2001) that performs the full Mie calculations once first to obtain a table of seven sets of Chebyshev expansion coefficients, and later the full Mie calculations are skipped and $\mathrm{Q}_{\mathrm{e}}$ and $\mathrm{Q}_{\mathrm{s}}$ are calculated using bilinear interpolation over the Chebyshev coefficients stored in the table. A detailed description of the computation of aerosol optical properties in WRF-Chem can be found in Fast et al. (2006) and Barnard et al. (2010).

The WRF-Chem model was used by Zhao et al. (2010) to investigate the sensitivities in simulating the size distributions and optical properties of Saharan dust to emitted dust size distributions and aerosol treatments during the dry season (from January to February) of 2006. In this study, the model domain covers West Africa $\left(36.15^{\circ} \mathrm{W}-\right.$ $\left.40.15^{\circ} \mathrm{E}, 9.2^{\circ} \mathrm{S}-37.0^{\circ} \mathrm{N}\right)$ using $200 \times 150$ grid points at $36 \mathrm{~km}$ horizontal resolution centering at Niamey (Niger) $\left(2.0^{\circ} \mathrm{E}, 13.6^{\circ} \mathrm{N}\right)$, and 35 vertical layers with model top pressure at $10 \mathrm{hPa}$. The simulation is conducted from 15 April 2006 to 30 September 2006. Only the results from 1 May 2006 to 30 September 2006 (referred as the simulation period hereafter) are used in the analysis to minimize the impact from the chemical initial conditions, and the simulated results from $170 \times 120$ interior points $\left(28.9^{\circ} \mathrm{W}-32.9^{\circ} \mathrm{E}\right.$, $5.0^{\circ} \mathrm{S}-32.1^{\circ} \mathrm{N}$ ) are used to minimize the influence from the lateral boundary conditions. We use the same model configuration as Zhao et al. (2010), except that the rapid radiative transfer model (RRTMG) (Mlawer et al., 1997; Iacono et al., 2000) for both SW and LW radiation is updated to include aerosol direct radiative effect. The MADE/SORGAM aerosol module with the GOCART dust emission scheme is used in this study as described in Zhao et al. (2010). Zhao et al. (2010) found $\sim 10 \%$ difference in the dust SW radiative forcing between the modal and sectional approaches in WRF-Chem over West Africa during the dry season. In our control simulation, we use the same SW refractive index $(1.53+0.003 i)$ of dust as Zhao et al. (2010). Modeling sensitivity of dust radiative impact on precipitation to dust SW absorptivity will be discussed in section 4.2. The Lin cloud microphysics scheme is used as described by Gustafson et al. (2007) to account for cloud chemistry, aerosol wet deposition, and aerosol indirect radiative effect. The Grell convective scheme is used to allow the feedback from the parameterized convective cloud to the radiation schemes. In the available version (v3.1.1) of WRF-Chem during this study, the Lin cloud microphysics and Grell convective schemes are the only parameterizations that are coupled with the full aerosol processes (including cloud chemistry and wet deposition) and cloud radiative feedback (WRF-Chem user guide from http://ruc.noaa.gov/wrf/WG11/Users_guide.pdf).

Large-scale meteorological fields are assimilated with lateral boundary and initial conditions from the NCEP/NCAR Global reanalysis data, which also provide the prescribed sea surface temperature (SST) for the simulations. Chemical lateral boundary conditions are from the default pro- files in WRF-Chem, which are based on the averages of mid-latitude aircraft profiles from several field studies over the eastern Pacific Ocean (McKeen et al., 2002). Anthropogenic emissions are obtained from the Reanalysis of the TROpospheric (RETRO) chemical composition inventories (http://retro.enes.org/index.shtml). Biomass burning emissions are obtained from the Global Fire Emissions Database, Version 2 (GFEDv2.1) with 8-day temporal resolution (Randerson et al., 2005) and vertically distributed following the injection heights suggested by Dentener et al. (2006) for the Aerosol InterComparison project (AeroCom), because of insufficient information to perform plume rise calculations over West Africa.

\section{Observations}

\subsection{AERONET surface observation network}

The Aerosol Robotic Network (AERONET) (Holben et al., 1998) with $\sim 100$ identical globally distributed sun- and sky-scanning ground-based automated radiometers provides measurements of aerosol optical properties throughout the world (Dubovik and King, 2000; Dubovik et al., 2002). In this study, AERONET measured aerosol optical depth (AOD) at $675 \mathrm{~nm}$ and $440 \mathrm{~nm}$ from six sites over West Africa are used to derive the AOD at $550 \mathrm{~nm}$ (using the Angström exponent) for comparison with model results. These six sites are Banizoumbou $\left(13^{\circ} \mathrm{N}, 2^{\circ} \mathrm{E}\right)$ and IER Cinzana $\left(13^{\circ} \mathrm{N}\right.$, $\left.5^{\circ} \mathrm{W}\right)$ over the Sahel region, Djougou $\left(9^{\circ} \mathrm{N}, 1^{\circ} \mathrm{E}\right)$ and Ilorin $\left(8^{\circ} \mathrm{N}, 4^{\circ} \mathrm{E}\right)$ over the southern biomass burning region, Dakar $\left(14^{\circ} \mathrm{N}, 16^{\circ} \mathrm{W}\right)$ at the coast, and Capo Verde $\left(16^{\circ} \mathrm{N}, 22^{\circ} \mathrm{W}\right)$ on a near-coast island. All of the retrievals of AOD are quality level 2, and the uncertainty of AOD measurements is about \pm 0.01 (Holben et al., 2001).

\subsection{MODIS}

The Moderate Resolution Imaging Spectroradiometer (MODIS) instruments on board the NASA Terra and Aqua platforms are uniquely designed with wide spectral range, high spatial resolution, and near daily global coverage to observe and monitor the Earth changes including tropospheric aerosols (Kaufman et al., 1997). The standard MODIS aerosol product does not retrieve aerosol information over bright surfaces (e.g., Sahara desert) due to a strong surface spectral contribution in the visible range (Kaufman et al., 1997). However, recently, a new algorithm, called the "Deep Blue algorithm" (Hsu et al., 2006), has been integrated with the existing MODIS algorithm to retrieve AOD even over bright surfaces. Therefore, in this study, the retrieved "deep blue" AOD from MODIS (Collection 5) (only available over land and from the MODIS on Aqua so far) (Levy et al., 2007; Remer et al., 2005) is used over land, while the standard retrieved AOD is used over the ocean. The MODIS on board the Aqua platform passes over the equator at $\sim 13: 30 \mathrm{LT}$ 


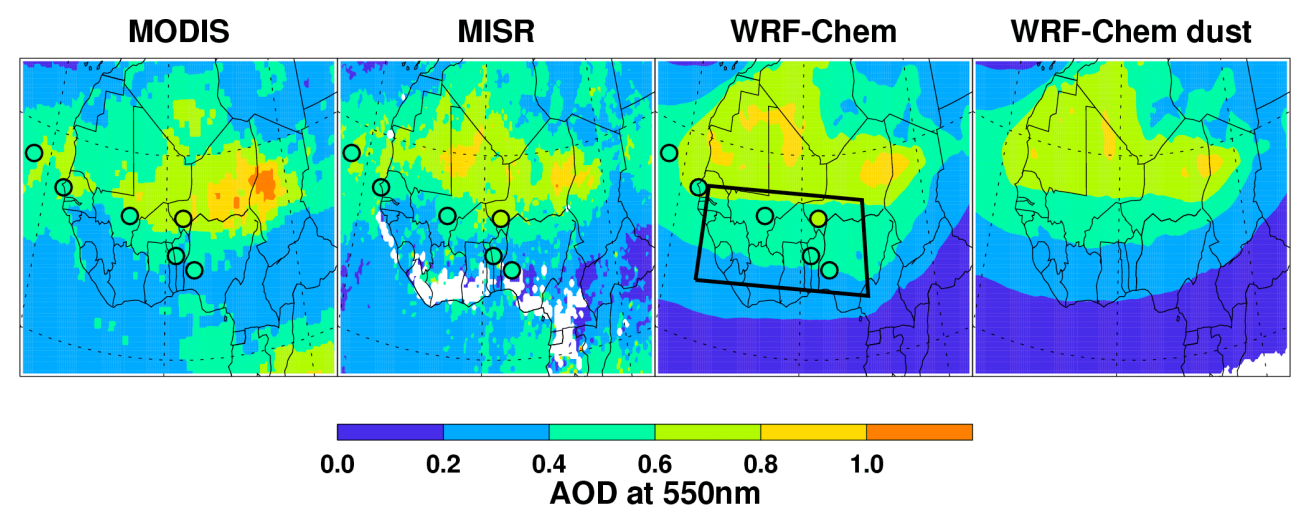

Fig. 1. Averaged AOD at $550 \mathrm{~nm}$ over West Africa from the retrievals of MODIS on Aqua and MISR on Terra, the measurements of six AERONET sites, and the corresponding WRF-Chem simulated AOD of total aerosols and dust-only. The MODIS retrievals are a combination of the standard (over ocean) and "Deep Blue" (over land) products. AERONET measurements and model results are sampled between 10am$14 \mathrm{pm}$. The blank areas in the plots are due to missing data. The six filled circles represent the averaged AOD at the six AERONET sites. The region in the black box is defined as the West Africa Monsoon (WAM) region.

during daytime (Kaufman et al., 1997). When comparing model simulated AOD with MODIS retrievals, model results are sampled in the same overpass time as Aqua.

\subsection{MISR}

The Multi-angle Imaging SpectroRadiometer (MISR) instrument on board the NASA Terra platform has been producing AOD globally since February 2000. MISR observes continuously at nine distinct zenith angles, ranging from $70^{\circ}$ afterward to $70^{\circ}$ forward, and in four narrow spectral bands centered at 446, 558, 672, and $866 \mathrm{~nm}$. MISR's unique blend of directional and spectral data allows aerosol retrieval algorithms to be used that do not depend on the explicit radiometric surface properties. As such, MISR can retrieve aerosol properties even over highly reflective surfaces like deserts (Diner et al, 1998; Martonchik et al., 2004). The MISR on board the Terra platform passes over the equator at $\sim$ 10:45 LT during daytime (Diner et al, 2001). When comparing model simulated AOD with MISR retrievals, model results are sampled in the same overpass time as Terra.

\subsection{ARM MPL lidar}

The US Department of Energy's Atmospheric Radiation Measurements (ARM) Program Mobile Facility (AMF) was fully equipped with comprehensive instrumentation and was located at the Niamey airport, which is $\sim 60 \mathrm{~km}$ northwest from the AERONET Banizoumbou site, from January through December in 2006 (Miller and Slingo, 2007). The downwelling SW and LW radiative fluxes at the surface measured by the AMF are used in this study. Uncertainties in the AMF measured radiative fluxes are given by Slingo et al. (2006) as $9.0 \mathrm{~W} \mathrm{~m}^{-2}$ for the total downwelling shortwave, although this could be as large as $25 \mathrm{~W} \mathrm{~m}^{-2}$ during dust storms, and $5.1 \mathrm{~W} \mathrm{~m}^{-2}$ for the downwelling longwave.
Details of the AMF instruments and their characteristics can be found in Miller and Slingo (2007).

\subsection{Outgoing Longwave Radiation (OLR) data}

The dataset of multiple-satellite retrieved daily mean OLR at $2.5^{\circ} \times 2.5^{\circ}$ for $1974-2010$ is available from the NCAR archives, with gaps filled by temporal and spatial interpolation. Detailed description of the dataset can be found in Liebmann and Smith (1996).

\subsection{GPCP 1-Degree Daily precipitation dataset}

The 1-Degree Daily (1DD) precipitation data are available from the GPCP Global Merge Development Center in the NASA/GSFC Laboratory for Atmospheres. The data are estimated at a one-degree daily resolution from multi-satellite observations (Huffman et al., 2001). The current dataset extends from October 1996 to present. The primary product in the 1DD dataset is a combined observation-only dataset.

\subsection{TRMM}

The 3B-42 product of the Tropical Rainfall Measuring Mission (TRMM) data is used. The purpose of algorithm 3B-42 is to produce TRMM merged high quality (HQ)/infrared (IR) precipitation and root-mean-square (RMS) precipitationerror estimates. These gridded estimates are on a 3-hour temporal resolution and a 0.25 -degree by 0.25 -degree spatial resolution in a global belt extending from $50^{\circ} \mathrm{S}$ to $50^{\circ} \mathrm{N}$ latitude. Detailed description of the dataset can be found in Huffman et al. (2001 and 2007). 

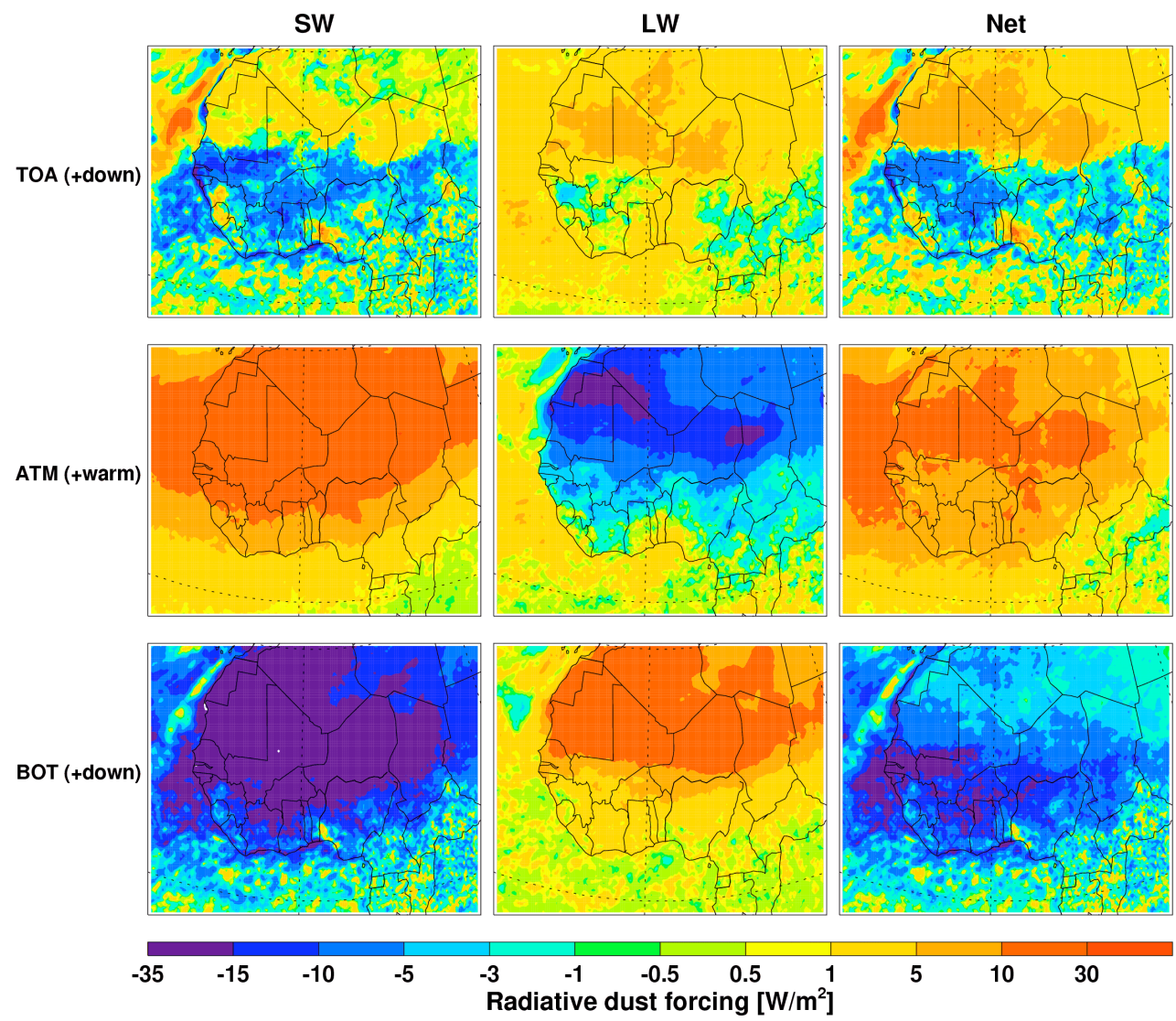

Fig. 2. Averaged all-sky SW and LW radiative forcing of dust over West Africa from WRF-Chem simulations. "TOA (+down)" represents the dust radiative forcing at the top of atmosphere and positive refers to downward direction; "ATM (+warm)" represents the dust radiative forcing in the atmosphere and positive refers to warming effect; "BOT (+down)" represents the dust radiative forcing at the surface and positive refers to downward direction. "Net" represents the sum of dust SW and LW radiative forcing.

\section{Results and discussion}

\subsection{Radiative forcing of mineral dust}

Figure 1 shows the mean spatial distribution of AOD at $550 \mathrm{~nm}$ from MISR and MODIS satellite retrievals, the AERONET measurements at six sites, and the corresponding WRF-Chem simulated AOD of total aerosols and dustonly during the simulation period over West Africa. Since the over-pass time of Terra (MISR) and Aqua (MODIS) is local time 10:45 a.m. and 1:45 p.m. respectively and the AERONET measurements are not always available at the time, the average of AERONET measurements and model results are sampled at the time period of 10 a.m. -2 p.m. In general, MISR and MODIS show consistent spatial patterns of AOD with a correlation coefficient of 0.68 . The measurements from six AERONET sites (color-filled circles in Fig. 1) are also consistent with satellite retrievals. WRF-Chem generally reproduces the spatial distribution of satellite retrieved AOD, except for the low bias near the southern boundary. Since the biomass burning aerosol emissions over the simu- lation domain during the WAM season are small (not shown), the low bias may result from the idealized chemical boundary conditions (McKeen et al., 2002) that cannot account for the biomass burning aerosols potentially transported from South Africa. The WRF-Chem simulated dust AOD shows that dust is the dominant source of aerosols during the summer monsoon season over West Africa.

Figure 2 shows the model simulated 24-h averaged spatial distribution of dust $\mathrm{SW}, \mathrm{LW}$, and net $(\mathrm{SW}+\mathrm{LW})$ radiative forcing at the top and bottom of the atmosphere and in the atmosphere during the simulation period over West Africa. At the top of atmosphere (TOA), the dust SW radiative forcing is positive or close to zero over the desert region, because of the high albedo values of desert and dust SW absorption. The change of sign of dust SW radiative forcing along $17^{\circ} \mathrm{N}$ is due to a sharp decrease of surface albedo between the Sahara desert in the north and the Sudanian savannas in the south and a decrease of dust loading away from the source regions. The domain averaged (average over the entire domain $\left.\left(28.9^{\circ} \mathrm{W}-32.9^{\circ} \mathrm{E}, 5.0^{\circ} \mathrm{S}-32.1^{\circ} \mathrm{N}\right)\right)$ dust $\mathrm{SW}$ radiative forcing at TOA is $-1.35 \mathrm{~W} \mathrm{~m}^{-2}$. The dust $\mathrm{LW}$ radiative forcing 
Table 1. WRF-Chem simulated 24-h all-sky radiative forcing of Saharan dust over West Africa $\left(28.9^{\circ} \mathrm{W}-32.9^{\circ} \mathrm{E}, 5.0^{\circ} \mathrm{S}-32.1^{\circ} \mathrm{N}\right)$ during the simulation period. The unit of values is $\mathrm{W} \mathrm{m}^{-2}$. "TOA" represents "top of atmosphere"; "ATM" represents "atmosphere"; "BOT" represents "surface". Positive means downward for TOA and BOT, positive for absorption/heating in ATM.

\begin{tabular}{llll}
\hline & SW & LW & NET \\
\hline TOA & -1.35 & 2.18 & 0.83 \\
ATM & 11.01 & -4.07 & 6.94 \\
BOT & -12.37 & 6.25 & -6.11 \\
\hline
\end{tabular}

at TOA is mostly positive over the domain with an average of $2.18 \mathrm{~W} \mathrm{~m}^{-2}$, resulting from dust LW absorption. Overall, the simulated dust net $(\mathrm{SW}+\mathrm{LW})$ radiative forcing (domain average of $0.83 \mathrm{~W} \mathrm{~m}^{-2}$ ) at TOA is consistent with the result reported by Balkanski et al. (2007). In the atmosphere, dust aerosol absorbs SW and warms the atmosphere. Dust LW effect cools the atmosphere by increasing atmospheric outgoing LW radiation. The dust LW forcing is higher over the desert because of hotter desert surface and stronger interaction between LW and coarse mode dust particles that are spatially confined to the desert due to their shorter lifetimes and distance being carried. In the atmosphere, dust produces a net $(\mathrm{LW}+\mathrm{SW})$ warming effect with a domain average of $6.94 \mathrm{~W} \mathrm{~m}^{-2}$. At the surface, dust has a cooling effect (domain average of $-12.37 \mathrm{~W} \mathrm{~m}^{-2}$ ) by reducing the downward SW radiation and a warming effect (domain average of $6.25 \mathrm{~W} \mathrm{~m}^{-2}$ ) by trapping the $\mathrm{LW}$ radiation emitted from surface. The net $(\mathrm{LW}+\mathrm{SW})$ dust radiative forcing at the surface is $-6.11 \mathrm{~W} \mathrm{~m}^{-2}$. The simulated dust radiative forcings averaged over the domain are summarized in Table 1. Overall, the net $(\mathrm{LW}+\mathrm{SW})$ radiative effect of dust is atmospheric warming, surface cooling, and relatively small net TOA forcing over West Africa.

The model simulated surface SW radiative fluxes are compared to the AMF retrievals. Diurnal cycle of upward and downward SW radiative fluxes at the surface at Niamey airport averaged during the simulation period from the AMF retrievals and WRF-Chem simulations with and without dust aerosols are shown in Fig. 3. The AMF retrievals show noontime maximum SW radiative fluxes with daily averages of $49 \mathrm{~W} \mathrm{~m}^{-2}$ and $240 \mathrm{~W} \mathrm{~m}^{-2}$ for upward and downward fluxes respectively. The simulation with dust well captures the upward SW fluxes with a daily average of $50 \mathrm{~W} \mathrm{~m}^{-2}$. Compared to the simulation without dust, dust reduces the daily averaged upward $\mathrm{SW}$ fluxes by about $5 \mathrm{~W} \mathrm{~m}^{-2}$ and improves the simulation. For downward SW fluxes, the simulation without dust significantly overestimates the values with a daily average of $270 \mathrm{~W} \mathrm{~m}^{-2}$, while the simulation with dust well captures the AMF retrievals with a daily average of $244 \mathrm{~W} \mathrm{~m}^{-2}$. Dust reduces the downward $\mathrm{SW}$ fluxes by $\sim 25 \mathrm{~W} \mathrm{~m}^{-2}$ on daily average and up to $\sim 100 \mathrm{~W} \mathrm{~m}^{-2}$ near noontime, and significantly improves the model simulations.

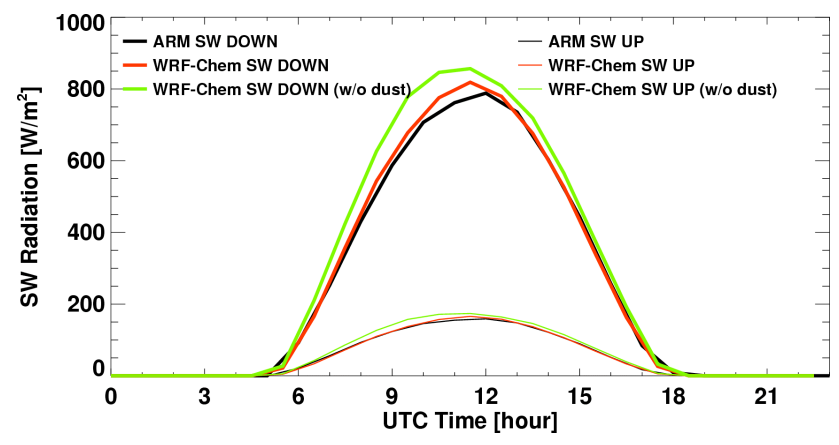

Fig. 3. Averaged diurnal cycle of upward and downward SW radiative fluxes at Niamey airport from the AMF retrievals and WRFChem simulations with and without dust aerosols.

Model simulated outgoing LW radiation (OLR) is compared using AVHRR retrievals. Figure 4 shows the monthly spatial distribution of OLR over West Africa during the simulation period from AVHRR retrievals and the WRF-Chem simulation. The AVHRR retrievals show higher OLR over the Sahara desert compared to the South and the ocean because of the hotter desert surface. Seasonally, OLR over the Sahara desert increases from May to July as the surface temperature increases. The model generally captures both the spatial patterns and monthly variation of retrieved OLR over West Africa, particularly over the Sahara. However, the model generally overestimates the OLR in the South (south to $\sim 20^{\circ} \mathrm{N}$ ). The bias is likely due to underestimation of cloud in the simulation. Sensitivity simulations using WRF with different cloud microphysics and convective schemes show that the OLR bias can be significantly reduced in the South (by up to $\sim 30 \mathrm{~W} \mathrm{~m}^{-2}$ compared to the OLR of $200 \sim 250 \mathrm{~W} \mathrm{~m}^{-2}$ ), suggesting that part of the bias comes from the Lin cloud microphysics and Grell convective schemes used in the control simulation. Dust reduces OLR by up to $\sim 10 \mathrm{~W} \mathrm{~m}^{-2}$ over the desert region (Fig. 2). Since the effect is relatively small compared to the OLR of $\sim 300 \mathrm{~W} \mathrm{~m}^{-2}$ over most part of the desert (Fig. 4), only results from the simulation with dust are shown in this figure.

\subsection{Radiative impact of dust on precipitation}

\subsubsection{Dust impact on precipitation}

Before investigating dust impact on precipitation, the WRFChem simulated precipitation is evaluated using GPCP and TRMM measurements. Figure 5 shows the daily zonal averaged precipitation between $15^{\circ} \mathrm{W}-10^{\circ} \mathrm{E}$ from GPCP and TRMM measurements and the WRF-Chem simulation during the simulation period. The Guinean coast is around $6^{\circ} \mathrm{N}$. Both GPCP and TRMM measurements show that the monsoon precipitation migrates from the southernmost region in May to the northernmost region in August, and retreats back to the south in September. WRF-Chem generally 

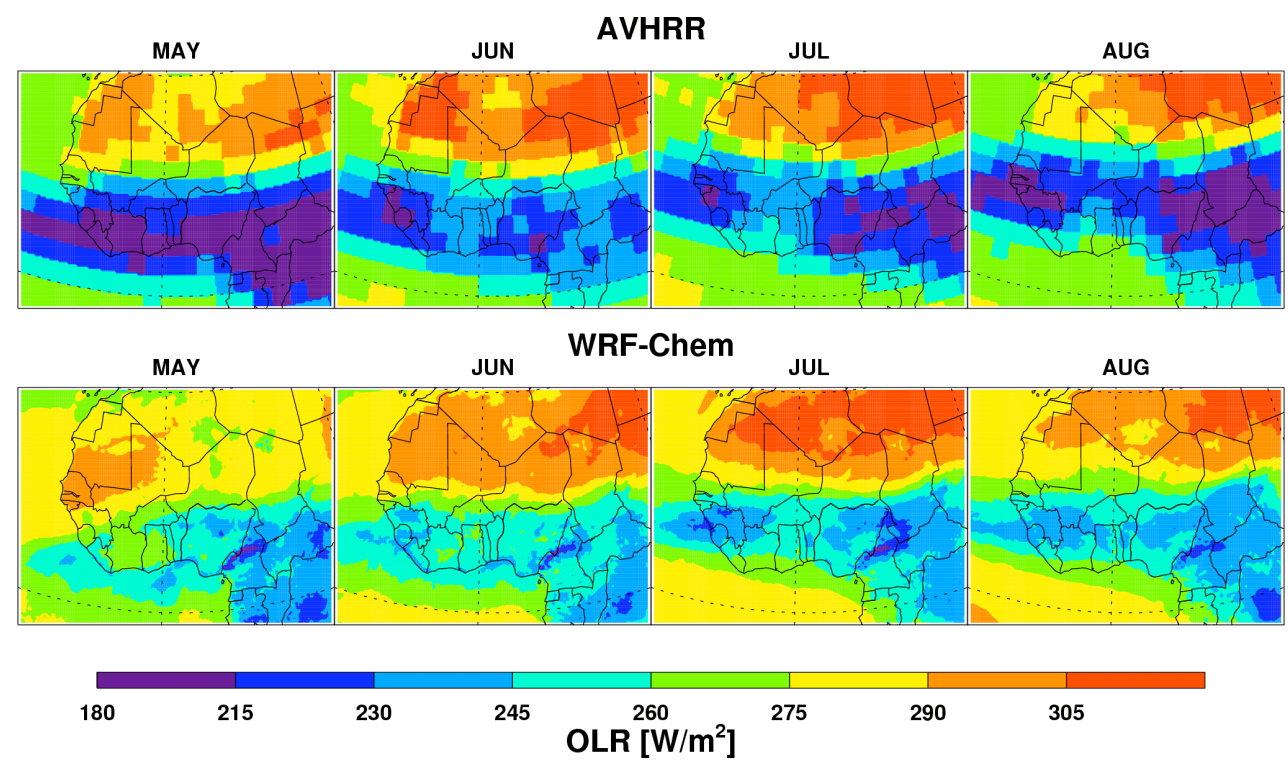

Fig. 4. Monthly spatial distribution of outgoing longwave radiative fluxes (OLR) over West Africa from the AVHRR retrievals and WRFChem simulations.
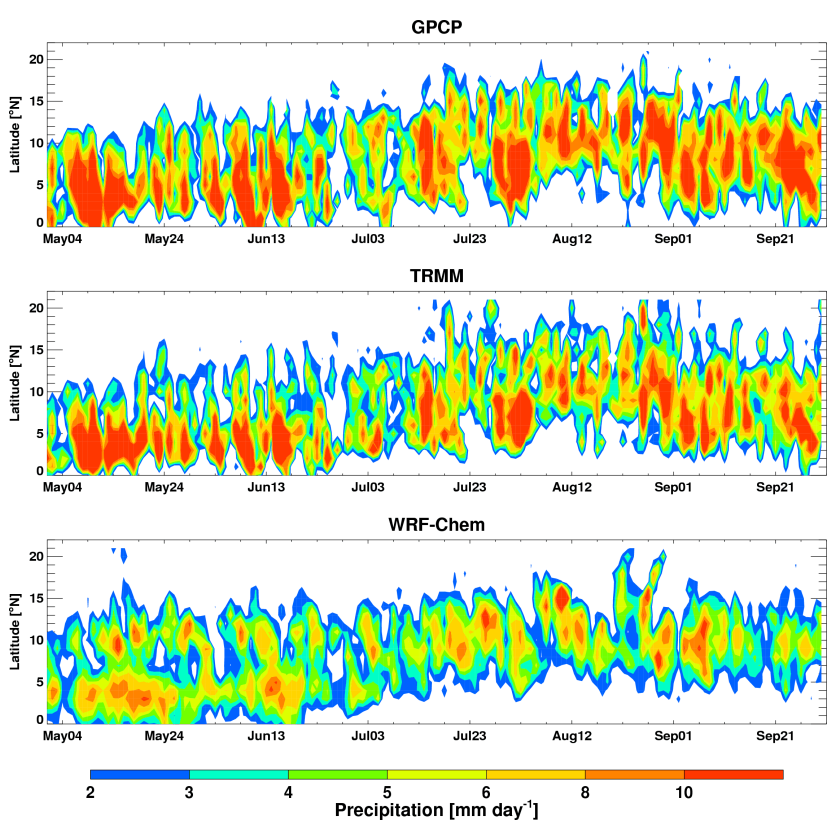

Fig. 5. Daily zonal averaged precipitation between $15^{\circ} \mathrm{W}-10^{\circ} \mathrm{E}$ from GPCP and TRMM measurements and the WRF-Chem control simulation.

well captures the seasonal migration of precipitation with a temporal correlation coefficient of 0.55 with both retrievals. However, WRF-Chem simulates an averaged precipitation rate of $3.0 \mathrm{~mm} /$ day during the simulation period, compared to $4.0 \mathrm{~mm} /$ day from GPCP and $3.6 \mathrm{~mm} /$ day from TRMM. This low bias mostly results from the model underestimation of heavy precipitation events $(>10 \mathrm{~mm} /$ day) during the
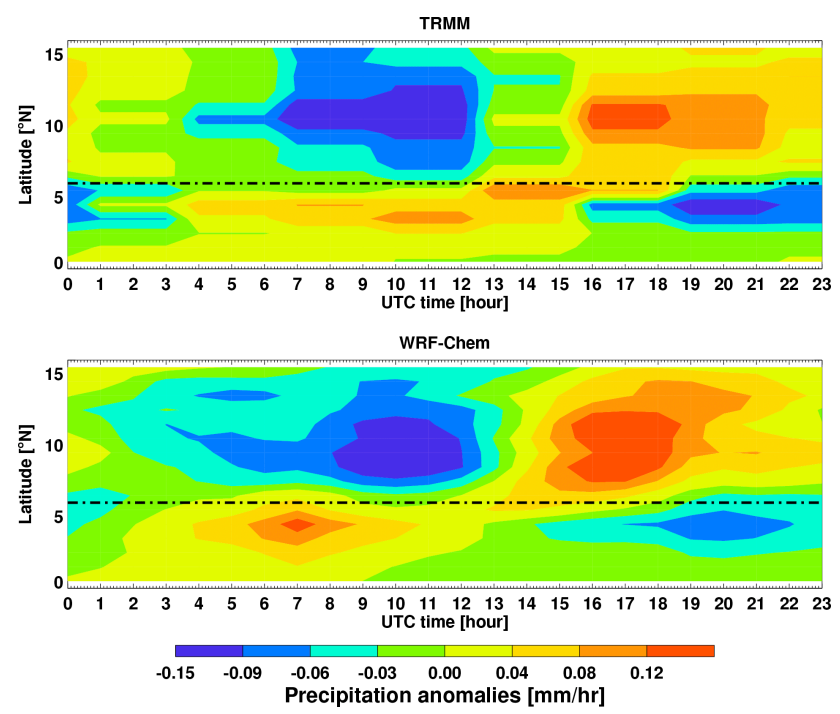

Fig. 6. Diurnal anomalies of zonal averaged precipitation between $15^{\circ} \mathrm{W}-10^{\circ} \mathrm{E}$ from TRMM measurements and the WRF-Chem simulation with dust. The TRMM data are shown in 3-h temporal resolution. The dashed line shows the Guinean coast. The diurnal anomalies are calculated by subtracting the daily mean precipitation from hourly precipitation.

monsoon season. The bias is partly related to the Lin cloud microphysics and Grell convective schemes. Simulations using WRF with different cloud microphysics and convective schemes show a reduction of the precipitation bias.

Besides seasonal changes, diurnal variability is a key feature of the monsoon precipitation over West Africa. Figure 6 

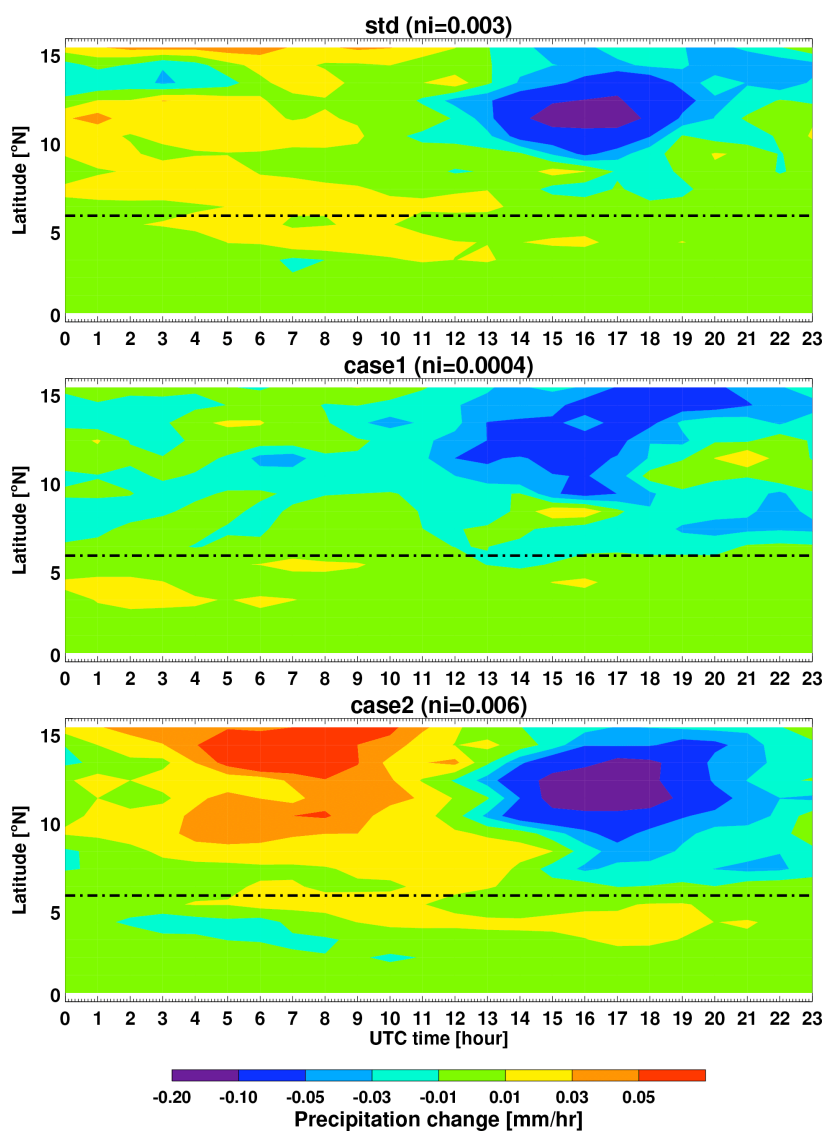

Fig. 7. Dust impact on the diurnal cycle of zonal averaged precipitation between $15^{\circ} \mathrm{W}-10^{\circ} \mathrm{E}$ from WRF-Chem in three cases with different dust absorption properties. The dashed line shows the Guinean coast. The dust impact is calculated by subtracting the precipitation from the simulation without dust from that with dust. " $n_{i}$ " represents the imaginary part of the refractive index of dust.

shows the diurnal anomalies of zonal averaged precipitation between $15^{\circ} \mathrm{W}-10^{\circ} \mathrm{E}$ from the TRMM measurements and WRF-Chem control simulation. The TRMM data are available in 3-hour temporal resolution. The dashed line shows the Guinean coast. The diurnal anomalies are calculated by subtracting the daily mean precipitation from the 3-hourly or hourly precipitation. The TRMM measurements show larger diurnal variation of precipitation over land than over the ocean (south of the dashed line), because surface heating that drives convection has much smaller diurnal change over the ocean due to its high heat capacity. Over land, solar heating of the surface can increase convective activity, leading to late afternoon precipitation (peak around $\sim 5$ p.m.). Over the ocean, the surface does not cool as much as the land due to the high heat capacity of the oceanic mixed-layer. As the atmosphere cools during nighttime, the atmosphere is destabilized by the warmer ocean surface. As a result, oceanic precipitation often peaks between midnight and early morning (Kim et al., 2010). The model generally captures the am-

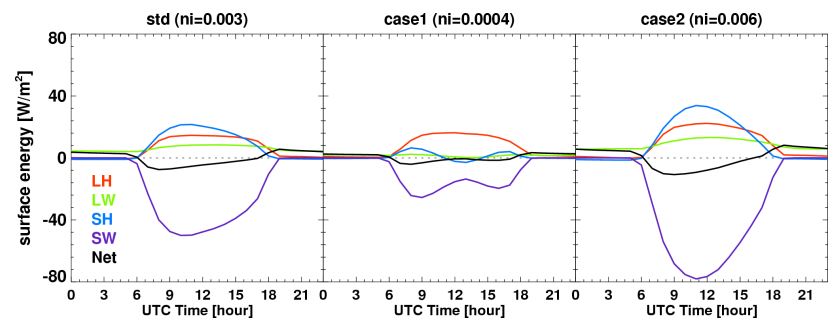

Fig. 8. Dust impact on the diurnal cycle of surface energy budget averaged over the WAM region $\left(6^{\circ} \mathrm{N}-17^{\circ} \mathrm{N}\right.$ and $\left.15^{\circ} \mathrm{W}-10^{\circ} \mathrm{E}\right)$ from WRF-Chem in three cases with different dust absorption properties. " $n_{i}$ " represents the imaginary part of the refractive index of dust. 'LH' is latent heat; "LW" is $\mathrm{LW}$ radiation; "SH" is sensible heat; "SW" is SW radiation; and "Net" is the sum of the total energy fluxes (i.e., $\mathrm{LH}+\mathrm{LW}+\mathrm{SH}+\mathrm{SW}$ ). Positive refers to more energy fluxes into the surface or less energy fluxes out of the surface.

plitude and phase of TRMM diurnal precipitation over both land and ocean.

Figure 7 shows the dust impact on diurnal cycle of zonal averaged precipitation between $15^{\circ} \mathrm{W}-10^{\circ} \mathrm{E}$ from the WRFChem simulations in three cases with different absorptivities of dust during the simulation period. The dashed line shows the Guinean coast. The dust impact is calculated by subtracting the precipitation from the simulation without dust from that of the simulation with dust. In the control simulation (the imaginary part $\left(n_{i}\right)$ of dust SW refractive index is set to 0.003 , i.e., $n_{i}=0.003$ ), dust reduces the late afternoon precipitation by up to $0.14 \mathrm{~mm} / \mathrm{h}(25 \%)$ but increases nocturnal and early morning precipitation by up to $0.04 \mathrm{~mm} / \mathrm{h}(45 \%)$ over land. The dust-induced reduction of diurnal precipitation amplitude with an average of $-0.06 \mathrm{~mm} / \mathrm{h}(-24 \%)$ over the WAM region $\left(6^{\circ} \mathrm{N}-17^{\circ} \mathrm{N}\right.$ and $15^{\circ} \mathrm{W}-10^{\circ} \mathrm{E}$, shown in Fig. 1) is $99 \%$ statistically significant based on the Student's t-test. Compared to the TRMM measurements (Fig. 6), the control simulation, which includes dust-induced reduction of diurnal amplitude, improves the simulation of diurnal cycle of precipitation over land. The dust impact on precipitation over the ocean is relatively small, because sea surface temperature is prescribed in this study. Even if sea surface temperature is simulated, dust effect is expected to be small within short-term because of its lower concentration over the ocean and the high heat capacity of the ocean. In the control simulation, dust reduces daily precipitation over the WAM region by $0.17 \mathrm{~mm} /$ day $(\sim 4 \%)$, which is relatively small because the late afternoon decrease and nocturnal and early morning increase of precipitation nearly offset each other.

To further investigate the dust impact on diurnal precipitation over the WAM region, the surface energy budget and atmospheric diabatic heating are analyzed. Figure 8 shows the dust impact on diurnal cycle of surface energy budget averaged over the WAM region from the WRF-Chem simulations in three cases with different SW absorptivities of dust. In the control simulation, dust reduces SW fluxes and 


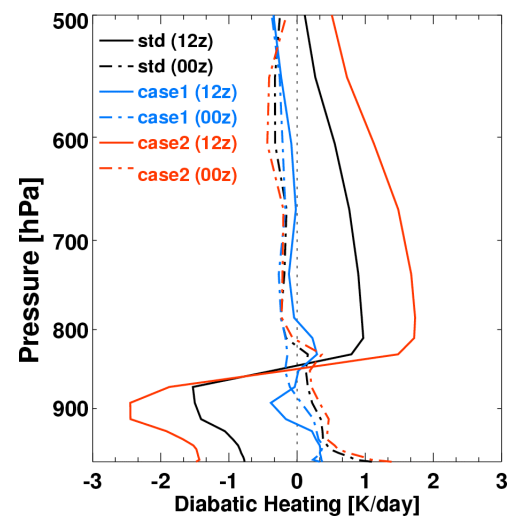

Fig. 9. Dust impact on the atmospheric diabatic heating profiles at 00:00 UTC and 12:00 UTC averaged over the WAM region $\left(6^{\circ} \mathrm{N}-\right.$ $17^{\circ} \mathrm{N}$ and $15^{\circ} \mathrm{W}-10^{\circ} \mathrm{E}$ ) from WRF-Chem simulations in three cases with different dust absorption properties: std $\left(n_{i}=0.003\right)$, case $1\left(n_{i}=0.0004\right)$, and case $2\left(n_{i}=0.006\right)$, where " $n_{i}$ " represents the imaginary part of the refractive index of dust.

increases LW fluxes into the surface, and reduces latent heat and sensible heat out of the surface in the daytime, because the land surface is cooler as a result of dust-induced reduction of downward SW radiation. In the nighttime, there is negligible dust impact on latent heat and sensible heat, but dust still increases LW fluxes into the surface due to the warming of the atmosphere. Overall, dust reduces the net surface energy in the daytime but increases the net surface energy in the nighttime, leading to surface cooling in the daytime and warming in the nighttime over the WAM region. Figure 9 shows the dust impact on atmospheric diabatic heating profiles at 00:00 UTC (mid-night) and 12:00 UTC (noontime) averaged over the WAM region $\left(6^{\circ} \mathrm{N}-17^{\circ} \mathrm{N}\right.$ and $15^{\circ} \mathrm{W}-$ $10^{\circ} \mathrm{E}$ ) from the WRF-Chem simulations in three cases with different dust absorption properties. In the control simulation (black line), dust cools the lower atmosphere (below $850 \mathrm{hPa}$ ) by up to $1.5 \mathrm{~K} /$ day and warms the atmosphere above by up to $1.0 \mathrm{~K} /$ day in the daytime, and warms the lower atmosphere by up to $1.2 \mathrm{~K} /$ day and cools the upper atmosphere by up to $0.3 \mathrm{~K} /$ day in the nighttime.

The dust-induced change of the surface energy and atmospheric diabatic heating profiles could modulate the stability of the atmosphere. The dust impact on equivalent potential temperature $(\mathrm{ETH})$ profiles, a quantity related to the stability of a column of air in the atmosphere, at 00:00 UTC (midnight) and 12:00 UTC (noontime) averaged over the WAM region from the WRF-Chem simulations is shown in Fig. 10. In general, a decrease of ETH in the lower atmosphere and an increase of ETH above indicate an increase of the atmospheric stability. In the control simulation (black line), in the daytime, dust reduces the lower atmospheric (below $850 \mathrm{hPa})$ ETH by $\sim 0.3 \mathrm{~K}$ and increases the ETH of the atmosphere above by $\sim 0.5 \mathrm{~K}$, leading to a more stable atmosphere. In the nighttime, dust increases the atmospheric ETH

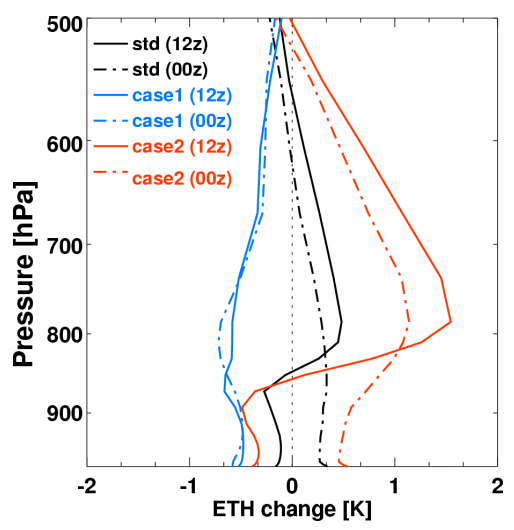

Fig. 10. Dust impact on the equivalent potential temperature (ETH) profiles at 00:00 UTC and 12:00 UTC averaged over the WAM region $\left(6^{\circ} \mathrm{N}-17^{\circ} \mathrm{N}\right.$ and $\left.15^{\circ} \mathrm{W}-10^{\circ} \mathrm{E}\right)$ from WRF-Chem simulations in three cases with different dust absorption properties: std $\left(n_{i}\right.$ $=0.003)$, case $1\left(n_{i}=0.0004\right)$, and case $2\left(n_{i}=0.006\right)$, where " $n_{i}$ " represents the imaginary part of the refractive index of dust.

below $600 \mathrm{hPa}$ by up to $\sim 0.3 \mathrm{~K}$ with larger impact in the lower atmosphere (below $800 \mathrm{hPa}$ ), leading to a less stable atmosphere. This dust-induced change of atmospheric stability constrains the buildup of convective cloud in the daytime and fosters the buildup of convective cloud in the nighttime. Convective precipitation accounts for over $90 \%$ of precipitation in the simulation and has a much larger value during daytime. Therefore, the net change is a reduction of the daily precipitation from larger reduction of daytime precipitation and smaller increase of nocturnal precipitation.

\subsubsection{Sensitivity of modeled dust impact on precipitation to dust solar absorptivity}

As shown in previous studies (e.g., Solmon et al., 2008; Lau et al., 2009), there are large uncertainties in the radiative forcing of Saharan dust due to the uncertainty in dust SW absorption. In this study, we provide an estimate of the sensitivity of precipitation variability to the dust SW absorptivity. We conduct two sensitivity simulations with different $n_{i}$ of dust at wavelengths around $550 \mathrm{~nm}$ suggested by previous studies (McConnell et al., 2010). Two additional simulations are performed using the lower $\left(n_{i}=0.0004\right.$, weaker absorbing) and upper $\left(n_{i}=0.006\right.$, stronger absorbing) bounds of $n_{i}$. The control simulation uses a value $\left(n_{i}=0.003\right)$ in the middle of the range. The dust impacts on precipitation from the two sensitivity simulations are also shown in Fig. 7. In the simulation with weaker absorbing dust, dust reduces precipitation over land by up to $0.1 \mathrm{~mm} / \mathrm{h}(19 \%)$ throughout the day, although it still reduces the diurnal precipitation amplitude with a WAM-region average of $-0.03 \mathrm{~mm} / \mathrm{h}(-12 \%)$ because larger reductions are simulated during daytime. Daily precipitation over the WAM region is significantly reduced by $0.52 \mathrm{~mm} /$ day $(12 \%)$. This is generally consistent with 
Table 2. WRF-Chem simulated mean dust effect on the daily precipitation and diurnal amplitude of precipitation over the WAM region $\left(6^{\circ} \mathrm{N}-\right.$ $17^{\circ} \mathrm{N}$ and $15^{\circ} \mathrm{W}-10^{\circ} \mathrm{E}$ ) during the wet monsoon season (May-September). The column "Mean (w/o dust)" shows the daily precipitation and diurnal amplitude of precipitation from WRF-Chem simulation without dust. " $n_{i}$ " represents the imaginary part of SW refractive index of dust.

\begin{tabular}{|c|c|c|c|c|c|c|}
\hline & \multicolumn{4}{|c|}{2006} & \multicolumn{2}{|c|}{2005} \\
\hline & Mean (w/o dust) & & Dust effect & & Mean (w/o dust) & Dust effect \\
\hline Daily Precipitation (mm/day) & 4.4 & $\begin{array}{c}n_{i}=0.003 \\
-0.17(-4 \%)\end{array}$ & $\begin{array}{c}n_{i}=0.0004 \\
-0.52(-12 \%)\end{array}$ & $\begin{array}{c}n_{i}=0.006 \\
0.03(1 \%)\end{array}$ & 4.0 & $\begin{array}{c}n_{i}=0.003 \\
-0.12(-3 \%)\end{array}$ \\
\hline Diurnal Amplitude $(\mathrm{mm} / \mathrm{h})$ & 0.25 & $-0.06(-24 \%)$ & $-0.03(-12 \%)$ & $-0.12(-48 \%)$ & 0.22 & $-0.05(-23 \%)$ \\
\hline
\end{tabular}

Yoshioka et al. (2007), who found that the $\sim 30 \%$ of Sahel rainfall reduction is due to weakly absorbing dust. The dust impact on the surface energy budget in the simulation with weaker absorbing dust is smaller than that in the control simulation, particularly for the increase of LW fluxes into the surface (Fig. 8). The dust impact on the atmospheric diabatic heating profile is relatively small (less than $0.3 \mathrm{~K} /$ day compared to $1.5 \mathrm{~K} /$ day in the control simulation) (Fig. 9). Therefore, the dust warming effect (through SW radiation absorption) cannot offset its cooling effect (through SW radiation extinction) at the lower atmosphere. As a result, dust reduces the atmospheric ETH below $500 \mathrm{hPa}$ by up to $\sim 0.6 \mathrm{~K}$ with larger impact in the lower atmosphere (below $800 \mathrm{hPa}$ ) (Fig. 10), leading to more stable atmosphere and hence less convective precipitation throughout the day.

In the simulation with stronger absorbing dust, compared to the result from the control simulation, dust reduces more late-afternoon precipitation by up to $0.2 \mathrm{~mm} / \mathrm{h}(38 \%)$ while increases more nocturnal and early morning precipitation by up to $0.11 \mathrm{~mm} / \mathrm{h}(150 \%)$, resulting in the largest reduction of diurnal precipitation amplitude with a WAM-region average of $-0.12 \mathrm{~mm} / \mathrm{h}(-48 \%)$ among the three cases (Fig. 7). The daily precipitation over the WAM region is increased by a very small amount of $\sim 0.03 \mathrm{~mm} /$ day $(\sim 1 \%)$. The dust impact on the surface energy budget is larger than that in the control simulation (Fig. 8). The dust cools the lower atmosphere (below $850 \mathrm{hPa}$ ) by up to $2.5 \mathrm{~K} /$ day and warms the atmosphere above by up to $2.0 \mathrm{~K} /$ day in the daytime, and warms the lower atmosphere by up to $1.4 \mathrm{~K} /$ day and cools the upper atmosphere by up to $0.5 \mathrm{~K} /$ day in the nighttime (Fig. 9). As a result, dust reduces the lower atmospheric (below $850 \mathrm{hPa}$ ) ETH by $\sim 0.5 \mathrm{~K}$ and increases the ETH of the atmosphere above by $\sim 1.5 \mathrm{~K}$ in the daytime, and increases the atmospheric ETH below $500 \mathrm{hPa}$ by up to $\sim 1.0 \mathrm{~K}$ with larger impact in the lower atmosphere (below $700 \mathrm{hPa}$ ) in the nighttime (Fig. 10). This dust-induced changes of surface energy and atmospheric diabatic heating profiles lead to even more stable atmosphere associated with less convective precipitation in the daytime and less stable atmosphere associated with more convective precipitation in the night and early morning. The mean dust effects on the daily precipitation and diurnal amplitude of precipitation over the WAM re- gion during the wet monsoon season (May-September) from the three simulations with different dust SW absorptivities are summarized in Table 2.

\subsubsection{Sensitivity of modeled dust impact on precipitation to interannual monsoon variability}

The dust effects discussed above are calculated from the simulations in the year of 2006, which is a relatively strong monsoon year. To examine possible dependence of our results on monsoon variability, a simulation $\left(n_{i}=0.003\right)$ has also been conducted for the weakest monsoon year 2005 in the last decade (2000-2009) based on GPCP observations (not shown). The averaged daily WAM precipitation $(4.0 \mathrm{~mm} /$ day $)$ in 2005 is $\sim 10 \%$ less than that $(4.4 \mathrm{~mm} /$ day $)$ in 2006. The simulations in 2005 show that dust reduces the late-afternoon precipitation by up to $0.10 \mathrm{~mm} / \mathrm{h}(21 \%)$, but increases nocturnal and early morning precipitation by up to $0.03 \mathrm{~mm} / \mathrm{h}(35 \%)$ over the WAM region, resulting in a reduction of diurnal precipitation amplitude with an average of $-0.05 \mathrm{~mm} / \mathrm{h}(-23 \%)$. There is a relatively small dust-induced change $(-0.12 \mathrm{~mm} /$ day or $-3 \%)$ of daily WAM precipitation. The results are also summarized in Table 2 . Comparing the difference between the control simulations for 2005 and 2006 with the difference among the three 2006 simulations with different dust SW absorptivities, the simulated dust impact on WAM precipitation is more sensitive to dust SW absorptivity than interannual monsoon variability, suggesting that more efforts in the future may focus on reducing the uncertainty in dust optical properties.

\subsection{Radiative impact of dust on atmospheric circulation}

The radiative impact of dust on atmospheric diabatic heating and stability could also modulate the atmospheric wind circulation (e.g., Lau et al., 2009). Figure 11 shows the spatial distributions of wind and dust-induced wind changes at $10 \mathrm{~m}$ and $700 \mathrm{hPa}$ over West Africa during the simulation period from WRF-Chem. In the figure, dust-induced wind speed changes in percentage are also shown. The model successfully simulates the monsoon circulation and the westerly jet in the lower atmosphere off the West African coast. The dust-induced change of wind speed at $700 \mathrm{hPa}$ is small 

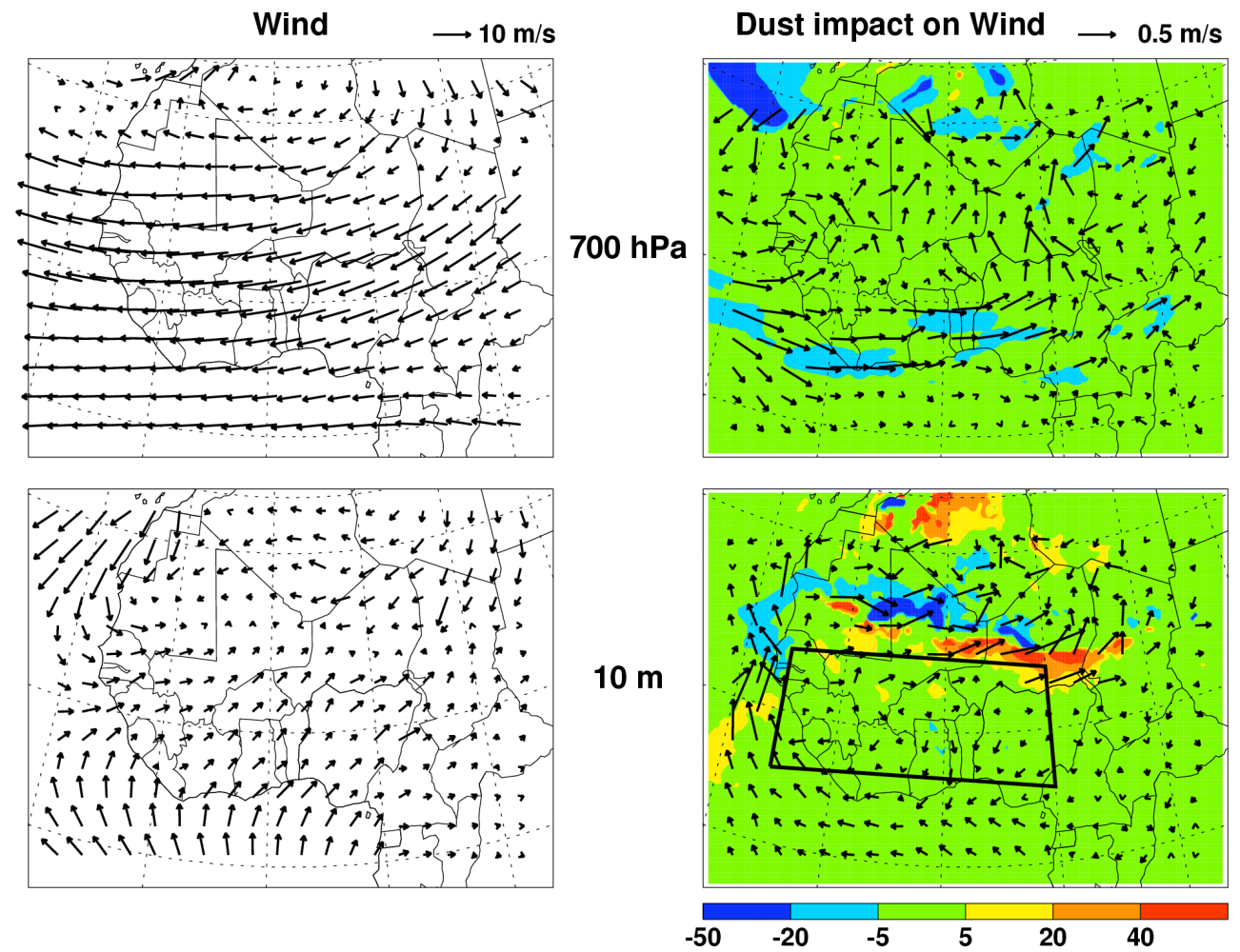

Fig. 11. Spatial distributions of wind and dust-induced wind changes at $10 \mathrm{~m}$ and $700 \mathrm{hPa}$ over West Africa from WRF-Chem. The wind is from the control simulation with dust; the dust-induced wind changes are estimated by subtracting the simulation without dust from that with dust. Dust-induced wind speed changes in percentage are also shown as contour. The region in the black box is defined as the West Africa Monsoon (WAM) region.

$(<5 \%)$, indicating that the large-scale monsoon circulation is not significantly changed by dust. The dust impact on largescale circulation may not be fully simulated using a regional modeling framework because the same atmospheric lateral boundary conditions and SST lower boundary conditions are used in the simulations with and without dust.

Although changes in the upper level winds are small, relatively larger changes ( $>5 \%$, up to $40 \%$ ) of $10 \mathrm{~m}$-wind speed are found over the Sahara desert. These changes are not statistically significant based on the Student's ttest with respect to day-to-day variation. These changes of wind speed near the surface result from the change of atmospheric stability. Since dust emissions in WRF-Chem are calculated online during the simulation, dust radiative feedback to its own emissions through changes in wind speed and/or soil moisture can be estimated. The model results show that dust radiative impact (primarily through changes in the surface wind) increases dust emissions by $\sim 8 \%$ from $\sim 110 \mathrm{Tg} /$ month in the simulation without dust to $118 \mathrm{Tg} / \mathrm{month}$ in the simulation with dust over West Africa during the simulation period. Although the $24 \mathrm{~h}$-averaged dust-induced change of $10 \mathrm{~m}$-wind speed is small $(<1 \%)$ over the WAM region, the diurnal cycle of $10 \mathrm{~m}$-wind is affected by dust. Figure 12 shows the dust impact on the di- urnal cycle of $10 \mathrm{~m}$-wind speed averaged over the WAM region from the control simulation (i.e., $n_{i}=0.003$ ). The dustinduced change of diurnal cycle of $10 \mathrm{~m}$-wind speed is consistent with the dust-induced ETH change (Fig. 10). Dust reduces $10 \mathrm{~m}$-wind speed by up to $0.13 \mathrm{~m} / \mathrm{s}(4 \%)$ when the ETH is reduced and increases $10 \mathrm{~m}$-wind speed by up to 0.14 $\mathrm{m} / \mathrm{s}(5 \%)$ when the ETH is increased. As a result, the diurnal variation of $10 \mathrm{~m}$-wind speed is significantly reduced by $\sim 10 \%$. This reduction is $95 \%$ statistically significant based on the Student's t-test. As dust emission varies non-linearly with wind speed, the change of diurnal wind speed results in an overall increase of dust emissions that provides a positive feedback, albeit small, to how dust influences the WAM.

\section{Conclusions}

In this study, the radiative forcing of Saharan dust and its feedback to the monsoon precipitation over the WAM region are investigated using the WRF-Chem model with a relatively high horizontal resolution of $36 \times 36 \mathrm{~km}^{2}$ and online calculation of dust emissions. The simulation runs from 15 April 2006 to 30 September 2006 covering West Africa. Both dust SW and LW direct radiative effect are included. 


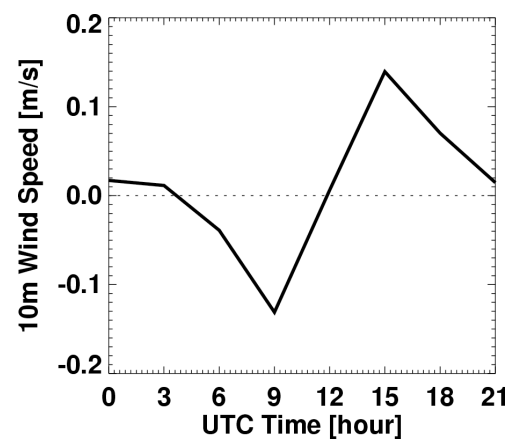

Fig. 12. Dust impact on the diurnal cycle of $10 \mathrm{~m}$-wind averaged over the WAM region $\left(6^{\circ} \mathrm{N}-17^{\circ} \mathrm{N}\right.$ and $\left.15^{\circ} \mathrm{W}-10^{\circ} \mathrm{E}\right)$ from the WRF-Chem control simulation (i.e., $n_{i}=0.003$ ).

Overall, the model successfully reproduces the observed features of aerosol, radiation, and monsoon precipitation during the simulation period over West Africa.

The model simulation shows that dust is the dominant source of aerosols during the summer monsoon season over West Africa. The domain averaged dust SW and LW radiative forcing at TOA is $-1.35 \mathrm{~W} \mathrm{~m}^{-2}$ and $2.18 \mathrm{~W} \mathrm{~m}^{-2}$, respectively. Overall, the simulated dust net $(\mathrm{SW}+\mathrm{LW})$ radiative forcing at TOA with a domain average of $0.83 \mathrm{~W} \mathrm{~m}^{-2}$ is consistent with previous studies (e.g., Balkanski et al., 2007; Lau et al., 2009). In the atmosphere, dust SW radiative effect warms the atmosphere while dust LW radiative effect cools the atmosphere. The net $(\mathrm{LW}+\mathrm{SW})$ dust radiative effect warms the atmosphere with a domain average of $6.94 \mathrm{~W} \mathrm{~m}^{-2}$. At the surface, dust has a SW cooling effect with a domain average of $-12.37 \mathrm{~W} \mathrm{~m}^{-2}$ and a LW warming effect with a domain average of $6.25 \mathrm{~W} \mathrm{~m}^{-2}$. The net $(\mathrm{LW}+\mathrm{SW})$ dust radiative forcing at the surface is $-6.11 \mathrm{~W} \mathrm{~m}^{-2}$. Overall, the net $(\mathrm{LW}+\mathrm{SW})$ radiative effect of dust is atmospheric warming, surface cooling, and relatively small TOA forcing over West Africa. The model simulated spatial distributions of dust radiative forcing over West Africa are generally consistent with previous studies using GCMs (e.g., Yoshioka et al., 2007; Lau et al., 2009).

In the control simulation $\left(n_{i}=0.003\right)$, dust modifies the surface energy budget and atmospheric diabatic heating, resulting in lower atmospheric cooling and upper atmospheric warming in the daytime and lower atmospheric warming in the nighttime over the WAM region. Therefore, the atmospheric ETH profiles are changed, leading to more stable atmosphere in the daytime and less stable atmosphere in the nighttime. As a result, dust reduces the late-afternoon precipitation by up to $0.14 \mathrm{~mm} / \mathrm{h}(25 \%)$, but increases nocturnal and early morning precipitation by up to $0.04 \mathrm{~mm} / \mathrm{h}(45 \%)$ over the WAM region. Dust-induced reduction of diurnal precipitation amplitude is $99 \%$ statistically significant based on the Student's t-test and improves the simulation of diurnal cycle of precipitation over land, compared to the TRMM measurements. The offset between the late afternoon decrease and nocturnal and early morning increase of precipitation results in a relatively small change of daily precipitation $(-0.17 \mathrm{~mm} /$ day or $-4 \%)$ over the WAM region. The dust impact on precipitation over the ocean is relatively small due to the prescribed SST. A previous study found that the Sahel climate response to dust radiative forcing is relatively insensitive to ocean coupling within short-term (Yoshioka et al., 2007). The small difference between the dust impacts in the control simulations for 2005 , a relatively weak monsoon year, and 2006, a wet monsoon year, suggest that our finding of dust impact on precipitation is robust and not sensitive to interannual monsoon variability.

Two sensitivity experiments with weaker-to-stronger absorbing dust show that the magnitude of dust impact on the surface energy is dependent on dust absorptivity. In the daytime, dust always cools the surface and the atmosphere below the dust layer. However, from weaker to stronger absorbing dust, in the daytime, dust introduces extra warming of the atmosphere. In the nighttime, dust LW warming effect surpasses its daytime SW cooling effect at the surface. This leads to anomalous warming over the land surface and the atmosphere below the dust layer and hence less stable atmosphere and more convective precipitation in the nighttime. As a result, weaker absorbing dust reduces the WAM precipitation by up to $0.1 \mathrm{~mm} / \mathrm{h}(19 \%)$ throughout the day, while stronger absorbing dust reduces late afternoon precipitation by up to $0.2(38 \%) \mathrm{mm} / \mathrm{h}$ but increases nocturnal and early morning precipitation by up to $0.11 \mathrm{~mm} / \mathrm{h}(150 \%)$. From weaker to stronger absorbing dust, the dust-induced change of daily WAM precipitation varies from significant reduction of $-0.52 \mathrm{~mm} /$ day $(-12 \%)$, which exceeds the average anomalies $(5 \%)$ of WAM precipitation in the last decade (2000-2009) analyzed from GPCP observations (not shown), to a small increase of $0.03 \mathrm{~mm} /$ day $(1 \%)$. Despite these differences, dust reduces the diurnal variation of precipitation regardless of its absorptivity, but more reduction is associated with more absorbing dust.

The dust-induced change of atmospheric stability also affects the surface wind speed. Unlike Jacobson and Kaufman (2006) who found up to $8 \%$ reduction in wind speed due to aerosol particles and the associated surface cooling and increased atmospheric stability, there is a difference in how dust influences wind speed due to its contrasting effects on radiation and atmospheric stability between day and night. Although dust-induced changes of the 24-h averaged surface wind speed is found to be small over the WAM region from our simulations, the diurnal variation of surface wind speed is significantly $(95 \%$ statistic significant based on the Student's t-test) reduced by $\sim 10 \%$. Overall, the change in diurnal wind speed leads to a $\sim 8 \%$ increase of dust emissions from $\sim 110 \mathrm{Tg} /$ month to $\sim 118 \mathrm{Tg} /$ month, providing a positive feedback mechanism on how dust influences the WAM climate. 
This study underscores the importance of including dust radiative effects in simulating the monsoon precipitation over the WAM region. Both dust SW and LW radiative effects are critical to assess the dust impact on precipitation, particularly for the diurnal cycle of precipitation, but dust LW radiative effect was not always included in previous studies (e.g., Konare et al., 2008). Although Kim et al. (2010) has demonstrated the significance of dust impact on diurnal cycle of precipitation, they used an atmospheric general circulation model with relatively coarse horizontal resolution $\left(2^{\circ} \times 2.5^{\circ}\right)$ and inaccurate simulation of the diurnal cycle of precipitation. Using a regional model, WRF-Chem, with relatively high horizontal resolution $\left(36 \times 36 \mathrm{~km}^{2}\right)$ that yields a better simulation of the monsoon precipitation, this study provides stronger evidence that dust affects the diurnal cycle of WAM precipitation. Our study further highlights the delicate balance between daytime and nighttime response of atmospheric stability and precipitation to dust, its sensitivity to solar absorptivity of dust, and how these factors influence the overall dust-induced change of WAM precipitation. More laboratory and field studies are needed to improve the characterization of dust SW absorption properties. In addition, dust SW absorption properties used in different modeling studies should be documented clearly for proper model-to-model comparisons.

Finally, several caveats should be noted in this study. First, dust can induce changes in diabatic heating in the atmosphere and surface. Depending on the strength and spatial distribution (both vertical and horizontal) of the changes, the monsoon circulation may change and influence the WAM precipitation. These effects cannot be fully simulated using a regional modeling framework because the same atmospheric lateral boundary conditions and SST lower boundary conditions are used in the simulations with and without dust. To fully investigate the potential effects of dust on monsoon circulation, a GCM should be used or lateral boundary conditions simulated by a GCM with and without dust should be used in the regional experiments. Second, although dust effect on stratiform cloud microphysics (i.e., indirect effect of dust) is included in our simulations, it is not a focus of our analysis, since convective precipitation dominates during the WAM season (generating over $90 \%$ of precipitation in the simulations). Dust effects on convective cloud and precipitation are not represented in the convective parameterization. In addition, dust aerosols can only be activated to cloud condensation nuclei (CCN) in the Lin microphysics scheme in this study, but dust can also be activated as ice nuclei (IN) to influence clouds and precipitation (e.g., DeMott et al., 2003, 2010). We intend to address these issues in future studies of dust effects to further elucidate the relative impacts of dust direct and indirect effects on monsoon precipitation. Last, the dust impact on the diabatic heating and hence the atmospheric stability is evident, however, the dustinduced changes of diurnal amplitude, diurnal phase (negligible in this study), and total amount of WAM precipitation may be sensitive to the cloud microphysics and convective schemes, which is beyond the scope of this study.

Acknowledgements. This study is supported by the Department of Energy Earth System Modeling Program Investigations on the Magnitude and Probabilities of Abrupt Climate TransitionS (IMPACTS) project. This research used computing resources from the National Energy Research Scientific Computing Center, which is supported by the Office of Science of the US Department of Energy under Contract No. DE-AC02-05CH11231. Pacific Northwest National Laboratory is operated for the US DOE by Battelle Memorial Institute under contract DE-AC06-76RLO330 1830.

Edited by: N. Riemer

\section{References}

Ackermann, I. J., Hass, H., Memmesheimer, M., Ebel, A., Binkowski, F. S., and Shankar, U.: Modal aerosol dynamics model for Europe: Development and first applications, Atmos. Environ., 32, 2981-2999, 1998.

Balkanski, Y., Schulz, M., Claquin, T., and Guibert, S.: Reevaluation of mineral aerosol radiative forcings suggests a better agreement with satellite and AERONET data, Atmos. Chem. Phys., 7, 81-95, doi:10.5194/acp-7-81-2007, 2007.

Barndard, J. C., Fast, J. D., Paredes-Miranda, G., Arnott, W. P., and Laskin, A.: Technical Note: Evaluation of the WRF-Chem "Aerosol Chemical to Aerosol Optical Properties" Module using data from the MILAGRO campaign, Atmos. Chem. Phys., 10, 7325-7340, doi:10.5194/acp-10-7325-2010, 2010.

DeMott, P. J., Sassen, K., Poellot, M. R., Baumgardner, D., Rogers, D. C., Brooks, S. D., Prenni, A. J., and Kreidenweis, S. M.: African dust aerosols as atmospheric ice nuclei, Geophys. Res. Lett., 30, 1732, 4 pp., doi:10.1029/2003GL017410, 2003.

DeMott, P. J., Prenni, A., Liu, X., Kreidenweis, S. M., Petters, M. D., Twohy, C. H., Richardson, M. S., Eidhammer, T., and Rogers, D. C.: Predicting global atmospheric ice nuclei distributions and their impacts on climate, Proc. Natl. Acad. Sci. USA, 107, 11217-11222, doi:10.1073/pnas.0910818107, 2010.

Dentener, F., Kinne, S., Bond, T., Boucher, O., Cofala, J., Generoso, S., Ginoux, P., Gong, S., Hoelzemann, J. J., Ito, A., Marelli, L., Penner, J. E., Putaud, J.-P., Textor, C., Schulz, M., van der Werf, G. R., and Wilson, J.: Emissions of primary aerosol and precursor gases in the years 2000 and 1750 prescribed data-sets for AeroCom, Atmos. Chem. Phys., 6, 4321-4344, doi:10.5194/acp6-4321-2006, 2006.

Diner, D. J., Beckert, J., Reilly, T., Bruegge, C., Conel, J., Kahn, R., Martonchik, J., Ackerman, T., Davies, R., Gerstl, S., Gordon, H. R., Muller, J. P., Myneni, R. B., Sellers, P. J., Pinty, B., and Verstraete, M.: Multi-angle Imaging SpectroRadiometer (MISR) instrument description and experiment overview, IEEE T., Geosci. Remote, 36, 1072-1087, 1998.

Diner, D. J., Abdou, W. A., Bruegge, C. J., Conel, J. E., Crean, K. A., Gaitley, B. J., Helmlinger, M. C., Kahn, R. A., Martonchik, J. V., and Pilorz, S. H.: MISR aerosol optical depth retrievals over southern Africa during the SAFARI-2000 dry season campaign, Geophys. Res. Lett., 28, 3127-3130, 2001. 
Dubovik, O. and King, M. D.: A ?exible inversion algorithm for retrieval of aerosol optical properties from sun and sky radiance measurements, J. Geophys. Res., 105, 20673-20696, 2000.

Dubovik, O., Holben, B., Eck, T. F., Smirnov, A., et al.: Variability of absorption and optical properties of key aerosol types observed in worldwide locations, J. Atmos. Sci., 59, 590-608, 2002.

Fast, J. D, Gustafson Jr., W. I., Easter, R. C., Zaveri, R. A., Barnard, J. C., Chapman, E. G., and. Grell, G. A.: Evolution of ozone, particulates, and aerosol direct forcing in an urban area using a new fully-coupled meteorology, chemistry, and aerosol model, J. Geophys. Res., 111, D21305, doi:10.1029/2005JD006721, 2006.

Fast, J., Aiken, A. C., Allan, J., Alexander, L., Campos, T., Canagaratna, M. R., Chapman, E., DeCarlo, P. F., de Foy, B., Gaffney, J., de Gouw, J., Doran, J. C., Emmons, L., Hodzic, A., Herndon, S. C., Huey, G., Jayne, J. T., Jimenez, J. L., Kleinman, L., Kuster, W., Marley, N., Russell, L., Ochoa, C., Onasch, T. B., Pekour, M., Song, C., Ulbrich, I. M., Warneke, C., WelshBon, D., Wiedinmyer, C., Worsnop, D. R., Yu, X.-Y., and Zaveri, R.: Evaluating simulated primary anthropogenic and biomass burning organic aerosols during MILAGRO: implications for assessing treatments of secondary organic aerosols, Atmos. Chem. Phys., 9, 6191-6215, doi:10.5194/acp-9-6191-2009, 2009.

Ghan, S., Laulainen, N., Easter, R., Wagener, R., Nemesure, S., Chapman, E., Zhang, Y., and Leung, R.: Evaluation of aerosol direct radiative forcing in MIRAGE, J. Geophys. Res., 106, 52955316, 2001.

Ginoux, P., Chin, M., Tegen, I., Prospero, J. M., Holben, B., Dubovik, O., and Lin, S.: Sources and distributions of dust aerosols simulated with the GOCART model, J. Geophys. Res., 106, 20225-20273, 2001.

Grell, G. A., Peckham, S. E., Schmitz, R., and McKeen, S. A., Frost, G., Skamarock, W. C., and Eder, B.: Fully coupled "online" chemistry within the WRF model, Atmos. Environ., 39, 69576976, 2005.

Gustafson, W. I., Chapman, E. G., Ghan, S. J., Easter, R. C., and Fast, J. D.: Impact on modeled cloud characteristics due to simplified treatment of uniform cloud condensation nuclei during NEAQS 2004, Geophys. Res. Lett., 34, L19809, doi:10.1029/2007GL0300321, 2007.

Holben, B. N., Eck, T. F., Slutsker, I., Tanr' e, D., Buis, J. P., Stezer, A., Vermote, E., Reagan, Y., Kaufman, U. J., Nakajima, T., Lavenu, F., Jankowiak, I., and Smirnov, A.: AERONET-A federated instrument network and data archive for aerosol characterization, Rem. Sens. Environ., 66, 1-16, 1998.

Holben, B. N., Tanre, D., Smirnov, A., ECK T. F., Slutsker, I., Abuhassan, N., Newcomb, W. W. Schafer, J. S., Chatenet, B., Lavenu, F., Kaufman, Y. J., Vande Castle, J., Setzer, A., Markham, B., Clark, D., Frouin, R., Halthore, R., A. Karneli O’Neill, N. T., Pietras, C., Pinker, R. T., Voss, K., and Zibordi, G.: An emerging ground-based aerosol climatology: Aerosol optical depth from AERONET, J. Geophys. Res., 106, 1206712097, 2001.

Hsu, N. C., Tsay, S., King, M., and Herman, J. R.: Deep blue retrievals of Asian Aerosol Properties during ACE-Asia, IEEE Tran. Geos. Remote Sen., 44, 3180, doi:10.1109/TGRS.2006.879540, 2006.

Huffman, G. J., Adler, R. F., Morrissey, M., Bolvin, D. T., Curtis, S., Joyce, R., McGavock, B., and Susskind, J.: Global Precipitation at One-Degree Daily Resolution from Multi-Satellite Observations, J. Hydrometeor., 2(1), 36-50, 2001.

Huffman, G. J., Adler, R. F., Bolvin, D. T., Gu, G., Nelkin, E. J., Bowman, K. P., Hong, Y., Stocker, E. F., and Wolff, D. B.: The TRMM Multi-satellite Precipitation Analysis: QuasiGlobal, Multi-Year, Combined-Sensor Precipitation Estimates at Fine Scale. J. Hydrometeor., 8(1), 38-55, 2007.

Iacono, M. J., Mlawer, E. J., Clough, S. A., and Morcrette, J.-J.: Impact of an improved longwave radiation model, RRTM. on the energy budget and thermodynamic properties of the NCAR community climate mode, CCM3. J. Geophys. Res., 105, 1487314890, 2000.

Jacobson, M. Z. and Y. J. Kaufman: Wind reduction by aerosol particles, Geophys. Res. Lett., 33, L24814, doi:10.1029/2006GL027838, 2006.

Kaufman, Y. J., Tanre, D., Remer, L. A., Vermote, E. F., Chu, A., and Holben, B. N.: Operational remote sensing of tropospheric aerosol over land from EOS moderate resolution imaging spectroradiometer, J. Geophys. Res., 102, 17051-17067, 1997.

Kim, K.-M., Lau, W. K.-M., Sud, Y. C., and Walker, G. K.: Influence of aerosol-radiative forcings on the diurnal and seasonal cycles of rainfall over West Africa and Eastern Atlantic Ocean using GCM simulations. Clim. Dyn., 35, 115-126, doi:10.1007/s00382-010-0750-1, 2010.

Konare, A., Zakey, A. S., Solmon, F., Giorgi, F., Rauscher, S., Ibrah, S., and Bi, X.: A regional climate modeling study of the effect of desert dust on the West African monsoon. J. Geophys. Res., 113, D12206, doi:10.1029/2007JD009322, 2008.

Lau, K. M., Kim, K. M., Sud, Y. C., and Walker, G. K.: A GCM study of the response of the atmospheric water cycle of West Africa and the Atlantic to Saharan dust radiative forcing, Ann. Geophys., 27, 4023-4037, 2009, http://www.ann-geophys.net/27/4023/2009/.

Leung, L. R., Kuo, Y. H., and Tribbia, J.: Research Needs and Directions of Regional Climate Modeling Using WRF and CCSM, Bull. Am. Meteorol. Soc., 87(12), 1747-1751, 2006.

Levy, R. C., Remer, L. A., Tanre, D., Kaufman, Y. J., Ichoku, C., Holben, B. N., Livingston, J. M., Russell, P. B., and Maring, H.: Evaluation of the Moderate-Resolution Imaging Spectroradiometer (MODIS) retrievals of dust aerosol over the ocean during PRIDE, J. Geophys. Res., 108, D198594, doi:10.1029/2002JD002460, 2003.

Liebmann B. and Smith, C. A.: Description of a Complete (Interpolated) Outgoing Longwave Radiation Dataset, Bull. Am. Meteorol. Soc., 77, 1275-1277, 1996.

Martonchik, J. V., Diner, D. J., Kahn, R., and Gaitley, B.: Comparison of MISR and AERONET aerosol optical depths over desert sites, Geophys. Res. Lett., 31, L16102, doi:10.1029/2004GL019807, 2004.

McConnell, C. L., Formenti, P., Highwood, E. J., and Harrison, M. A. J.: Using aircraft measurements to determine the refractive index of Saharan dust during the DODO experiments, Atmos. Chem. Phys., 10, 3081-3098, doi:10.5194/acp-8-30812010, 2010.

McKeen, S. A., Wotawa, G., Parrish, D. D., Holloway, J. S., Buhr, M. P., Hubler, G., Fehsenfeld, F. C., and Meagher, J. F.: Ozone production from Canadian wildfires during June and July of 1995, J. Geophys. Res., 107(D14), 4192, doi:10.1029/2001JD000697, 2002. 
Miller, R. L., Tegen, I., and Perlwitz, J.: Surface radiative forcing by soil dust aerosols and the hydrologic cycle, J. Geophys. Res., 109, D04203, doi:10.1029/2003JD004085, 2004.

Miller, M. A. and A. Slingo: The ARM Mobile Facility and its first international deployment: Measuring radiative flux divergence in West Africa, Bull. Am. Meteorol. Soc., 88, 1229-1244, doi:10.1175/BAMS-88-8-1229, 2007.

Mlawer, E. J., Taubman, S. J., P. D. Brown, M. J. Iacono and S. A. Clough: RRTM, a validated correlated-k model for the longwave, J. Geophys. Res., 102, 16663-16682, 1997.

Nickovic, S., Kallos, G., Papadopoulos, A., and Kakaliagou, O.: A model for prediction of desert dust cycle in the atmosphere, J. Geophys. Res., 106, 18113-18129, 2001.

Prospero, J. M. and Lamb, P. J.: African droughts and dust transport to the Caribbean: Climate change implications, Science, 302, 1024-1027, 2003.

Qian, Y, Gustafson, W. I. Jr., Leung, L. Y., and Ghan, S.: Effects of soot-induced snow albedo change on snowpack and hydrological cycle in western United States based on Weather Research and Forecasting chemistry and regional climate simulations, J. Geophys. Res., 114, D03108, doi:10.1029/2008JD011039, 2009.

Randerson, J. T., Van der Werf G. R., Giglio, L., Collatz, G. J., and Kasibhatla., P. S.: Global Fire Emissions Database, Version 2 (GFEDv2.1). available online at: http://daac.ornl.gov/ from Oak Ridge National Laboratory Distributed Active Archive Center, Oak Ridge, Tennesse, USA, doi:10.3334/ORNLDAAC/849, 2005.

Redelsperger, J. L., Thorncroft, C. D., Diedhiou, A., Lebel, T., Parker, D. J., and Polcher, J.: African Monsoon Multidisciplinary Analysis: An international research project and field campaign, A. Am. Meteorol. Soc., 87, 1739-1746, doi:10.1175/BAMS-8712-1739, 2006.

Remer, L. A., Kaufman, Y. J., Tanre, D., Mattoo, S., Chu, D. A., Martins, J. V., Li, R., Ichoku, C., Levy, R. C., Kleidman, R. G., Eck, T. F., Vermote, E., and Holben, B. N.: The MODIS aerosol algorithm, products and validation, J. Atmos. Sci., 62, 947-973, 2005.

Schell, B., Ackermann, I. J., Hass, H., Binkowski, F. S., and Ebel, A.: Modeling the formation of secondary organic aerosol within a comprehensive air quality modeling system, J. Geophys. Res., 106, 28275-28293, 2001.

Skamarock, W. C., Klemp, J. B., Dudhia, J., Gill, D. O., Barker, D. M., Duda, M. G., Huang, X., Wang, W., and Powers, J. G.: A description of the advanced research WRF version 3, NCAR Tech. Note, NCAR/TN-475+STR,, Natl. Cent. for Atmos. Res., Boulder, CO, USA, 8 pp. available online at: http://www.mmm. ucar.edu/wrf/users/docs/arw_v3.pdf, 2008.

Slingo, A., Ackerman, T. P., Allan, R. P., Kassianov, E. I., McFarlane, S. A., Robinson, G. J., Barnard, J. C., Miller, M. A., Harries, J. E., Russell, J. E., and Dewitte, S.: Observations of the impact of a major Saharan dust storm on the atmospheric radiation balance, Geophys. Res. Lett., 33, L24817, doi:10.1029/2006GL027869, 2006.
Solmon, F., Mallet, M., Elguindi, N., Giorgi, F., Zakey, A., and Konare, A.: Dust aerosol impact on regional precipitation over western Africa, mechanisms and sensitivity to absorption properties, Geophys. Res. Lett., 35, L24705, doi:10.1029/2008GL035900, 2008.

Stockwell, W. R., Middleton, P., Chang, J. S., and Tang, X.: The second generation regional acid deposition model chemical mechanism for regional air quality modeling, J. Geophys. Res., 95, 16343-16367, 1990.

Sultan, B., Baron, C., Dingkuhn, M., Sarr, B., and Janicot, S.: Agricultural impacts of large-scale variability of the West African monsoon, J. Agr. For. Meteorol., 128, 93-110, doi:10.1016/j.agrformet.2004.08.005, 2005.

Vigaud, N., Roucou, P., Fontaine, B., Sijikumar, S., and Tyteca, S.: WRF/ARPEGE-CLIMAT simulated climate trends over West Africa, Clim. Dynam., doi:10.1007/s00382-009-0707-4, 2009.

Wang, W. and Liu, X.: Evaluating deep updraft formulation in NCAR CAM3 with high resolution WRF simulations during ARM TWP-ICE, Geophys. Res. Lett., 36, L04701, doi:10.1029/2008GL036692, 2009.

Woodward, S.: Modeling the atmospheric life-cycle and radiative impact of mineral dust in the Hadley Centre climate model, J. Geophys. Res., 106, 18155-18166, 2001.

Yoshioka, M., Mahowald, N., Conley, A. J., Collins, W. D., Fillmore, D. W., Zender, C. S., and Coleman, D. B.: Impact of desert dust radiative forcing on Sahel precipitation: relative importance of dust compared to sea surface temperature variations, vegetation changes and greenhouse gas warming, J. Climate, 16, 14451467, doi:10.1175/JCLI4056.1, 2007.

Zaveri, R. A. and Peters, L. K.: A new lumped structure photochemical mechanism for large-scale applications, J. Geophys. Res., 104, 30387-30415, 1999.

Zaveri, R. A., Easter, R. C., Fast, J. D., and Peters, L. K.: Model for simulating aerosol interactions and chemistry (MOSAIC), J. Geophys. Res., 113, D13204, doi:10.1029/2007JD008792, 2008.

Zhang, Y., Duliere, V., Mote, P. W., Salathe Jr., E. P. : Evaluation of WRF and HadRM Mesoscale Climate Simulations over the U.S. Pacific Northwest, J. Climate, 22, 5511-5526, doi:10.1175/2009JCLI2875.1, 2009.

Zhao, C., Liu, X., Leung, L. R., Johnson, B., McFarlane, S. A., Gustafson Jr., W. I., Fast, J. D., and Easter, R.: The spatial distribution of mineral dust and its shortwave radiative forcing over North Africa: modeling sensitivities to dust emissions and aerosol size treatments, Atmos. Chem. Phys., 10, 8821-8838, doi:10.5194/acp-10-8821-2010, 2010. 